\title{
34. PLANKTONIC FORAMINIFER BIOSTRATIGRAPHY OF NORWEGIAN SEA SEDIMENTS: ODP LEG 104 1
}

\author{
Dorothee Spiegler ${ }^{2}$ and Eystein Jansen ${ }^{3}$
}

\begin{abstract}
Sites 642,643 , and 644 were investigated for planktonic foraminifers. Frequent occurrences of barren intervals caused by dissolution as well as low- diversity and long-ranging assemblages reduce the stratigraphic resolution of these records. Based on Neogloboquadrina species a local zonation, correlated with high-latitude North Atlantic schemes, is proposed for the middle Miocene to Quaternary and correlated with paleomagnetic records.

The middle to late Miocene boundary is defined by the last appearance datum of Neogloboquadrina mayeri and the first appearance datum of Neogloboquadrina acostaensis. Late Miocene age is defined by a $N$. acostaensis zone, whereas latest Miocene to Pliocene zones are defined by dextral and sinistrally coiling Neogloboquadrina atlantica. The top of the Pliocene is characterized by dextral and sinistrally coiling Neogloboquadrina pachyderma. The Pleistocene is defined by a nearly monospecific assemblage of Neogloquadrina pachyderma in its sinistrally coiled and encrusted variety.
\end{abstract}

\section{INTRODUCTION}

Leg 104 drilling provided, for the first time, the possibility of obtaining long and undisturbed continuous sequences of $\mathrm{Ce}$ nozoic sediments from the Norwegian Sea (Fig. 1 and Eldholm, Thiede, Taylor, et al., 1987). As DSDP Leg 38 used conventional rotary drilling, the records from that leg only provide an episodic stratigraphy. But with Leg 104 cores, we were able to make a detailed study of evolution of the foraminifer faunas present at high northern latitudes, both with the aim of producing a biostratigraphic framework and to reveal details of the climatic and oceanographic development of the area.

In this paper we report the planktonic foraminifer biozonation of the Leg 104 drill sites. Our main emphasis is on the biochronological and correlational aspects of the data, but we have also included some discussion on paleoenvironmental interpretations.

Establishing the planktonic foraminifer biostratigraphy and biochronology of the high-latitude North Atlantic region, including the Norwegian-Greenland Sea, has proved to be a difficult task. The major obstacle is the nature of the high-latitude faunas which are low-diversity faunas composed of long-ranging species. The standard zonation schemes established for tropical and temperate regions are generally not applicable in this area because the marker species used for the the zonal definitions are absent. Another problem stems from the lack of good, continuous carbonate-bearing sequences and the lack of magnetic time control in most holes.

The first zonation for the northern North Atlantic was put forward by Berggren (1972) from DSDP Leg 12. This was later expanded by Poore (1979) based on data from DSDP Leg 49. Lately, studies of Leg 94 sites have produced a much more detailed, high-latitude late Neogene zonation that is directly tied with magnetostratigraphy (Weaver, 1987; Weaver and Clement, 1986, 1987; Hooper and Weaver, 1987; Raymo et al., 1987). These papers also provide a series of datum levels for the North

\footnotetext{
${ }^{1}$ Eldholm, O., Thiede, J., Taylor, E., et al., 1989. Proc. ODP, Sci. Results, 104: College Station, TX (Ocean Drilling Program).

2 GEOMAR Research Center for Marine Geosciences at the Christian- Albrechts-University, Wischhofstrasse 1-3, Bldg. 4, D-2300 Kiel 14, Federal Republic of Germany.

${ }^{3}$ Department of Geology, Sect. B, University of Bergen, Allegaten 41 N-5007 Bergen, Norway.
}

Atlantic planktonic foraminifers, especially for the late Miocene and the Pliocene. This zonation and these datum levels are also useful for the interpretation of Leg 104 data and are used in the following discussion.

\section{MATERIAL AND METHODS}

We report results from analyses of Sites 642,643 , and 644 . Five holes were drilled at Site 642 . Hole 642A was analyzed at a resolution of one sample per section. Hole $642 \mathrm{~B}$ was analyzed at a sampling resolution of two samples per section through to Core 104-642B-9. The remainder of Hole 642B cores were analyzed one sample per section. From Hole $642 \mathrm{C}$ we analyzed two samples per section down to Core 104-642C-6 and one sample per section from the rest of the hole as well as from Hole 642D. Hole 642E comprised volcanic and volcaniclastic material. The volcaniclastic sediments were analyzed on board and were all barren of planktonic foraminifers. Only one hole was drilled at Site 643. The upper part of Hole 643A was analyzed in larger detail with seven samples per section through Core 104-643A-7 and one sample per section in the part below this level. Two holes were drilled at Site 644 . Hole $644 \mathrm{~A}$ was analyzed six to seven samples per section through Core 104-644A-5 and two to four samples per section in the rest of the hole. Hole 644B was not analyzed.

Sample volumes were $20 \mathrm{~cm}^{3}$ and all samples were prepared simply by drying and soaking in water before being washed on a $63-\mu \mathrm{m}$ screen. The analyses were carried out on the fraction $>125 \mu \mathrm{m}$.

Very little reworking was recognized except in the glacial sediments, which contain Cretaceous, Oligocene, and Miocene material derived from ice rafting (Spiegler, this volume). Although the sites were located in relatively shallow water (Table 1), calcite dissolution is a serious problem both in the Tertiary and Quaternary sediments (Henrich, this volume). Age determinations and zonal definitions become problematic where major parts of the fauna have been dissolved. As is shown later, some zonal boundaries fall within intervals barren of planktonic foraminifers, thus reducing the resolution of the proposed zonation. Another factor contributing to the same problem is the general low faunal diversity. Only 22 taxa are identified, mostly belonging to the Neogloboquadrina with some additional species of Globigerina, Globigerinoides, Globigerinita, Orbulina, and in Hole 644A Globoconella, Obandyella, and Globigerinella.

\section{TAXONOMIC NOTES}

Only Neogloboquadrina taxa are discussed because the entire zonation is based upon them.

\section{Neogloboquadrina acostaensis (Blow, 1959, PI. 1, Figures 9-12)}

The first appearance datum (FAD) of $N$. acostaensis has been used in the zonal schemes of Bolli (1966), Blow (1969), 


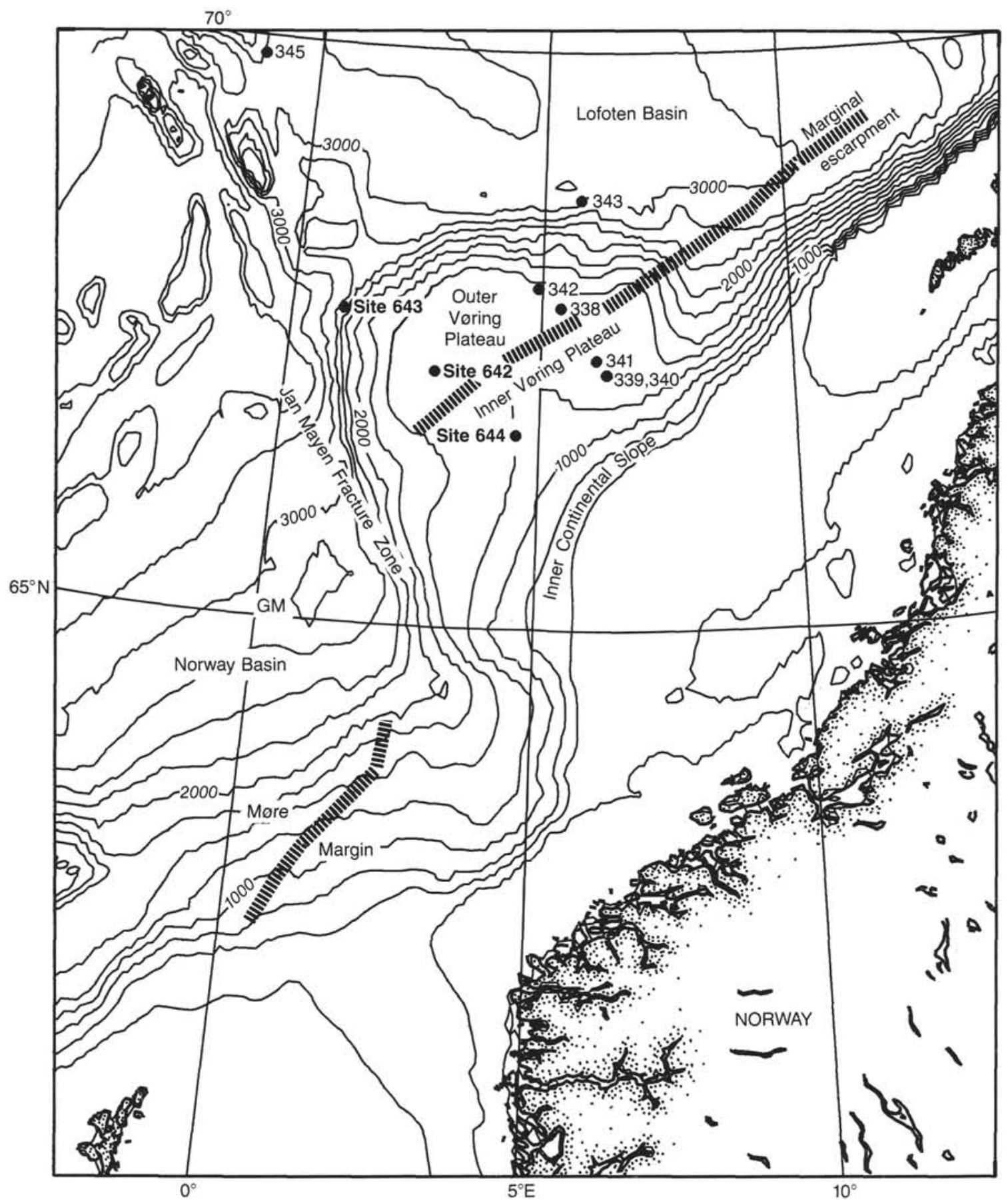

Figure 1. Vøring Plateau bathymetric and location Map of ODP Leg 104 sites. Contour interval, $250 \mathrm{~m}$.

Stainforth et al. (1975), Berggren et al. (1983), and also Bolli and Saunders (1985) to indicate the boundary of middle/late Miocene in tropical and subtropical areas. This first occurrence dates the base of upper Miocene from some sections at higher latitudes (Site 408, Poore, 1979, Table 3).

There is also a good agreement between the observations of Bolli and Saunders (1985, p. 210) and our observations from Site 642 about chamber formation and size frequency of $N$. acostaensis. The oldest, small specimens ( $270 \mu \mathrm{m}$ in diameter) at the base of the upper Miocene typically comprise 4 to $41 / 2$ chambers in the final whorl. The younger ones have 5 to $51 / 2$ chambers and reach a diameter of $420 \mu \mathrm{m}$. N. acostaensis is a warm-water species that only occurs sporadically at higher lati- tudes. Its last occurrence level was dated at about $2 \mathrm{Ma}$ by Hooper and Weaver $(1987$, p. 28$)$ for Leg 94 Sites but is not observed in sediments older than $5.5 \mathrm{Ma}$ in the Leg 104 holes, according to the time scale of Bleil (this volume) and Goll (this volume).

\section{Neogloboquadrina atlantica (Berggren, 1972). Pl. 1, Figure 6}

This species is a very useful marker in higher latitudes. It is adapted to cool environments (Berggren, 1972; 1984; Hooper and Funnell, 1986). In Leg 104 holes their first occurrences at $8.9 \mathrm{Ma}$, last occurrences at $1.84 \mathrm{Ma}$, and distinct coiling changes 
Table 1. Site locations and water depths, ODP Leg 104.

\begin{tabular}{|c|c|c|c|}
\hline Hole & Latitude & Longitude & $\begin{array}{l}\text { Water Depth } \\
\text { (m) }\end{array}$ \\
\hline $642 \mathrm{~A}$ & $67013.5^{\circ} \mathrm{N}$ & $02^{\circ} 55.7^{\prime} \mathrm{E}$ & 1286 \\
\hline $642 B$ & $67^{\circ} 13.5^{\prime} \mathrm{N}$ & $02^{\circ}{ }^{\circ} 5.7^{\prime} \mathrm{E}$ & 1286 \\
\hline $642 \mathrm{C}$ & $67013.2^{\circ} \mathrm{N}$ & $02055.8^{\prime} \mathrm{E}$ & 1277 \\
\hline 642D & $67^{\circ} 13.2^{\circ} \mathrm{N}$ & $02^{\circ} 55.8^{\circ} \mathrm{E}$ & 1277 \\
\hline $642 \mathrm{E}$ & $67013.2^{\circ} \mathrm{N}$ & $02^{\circ} 55.8^{\circ} \mathrm{E}$ & 1277 \\
\hline $643 A$ & $67042.9^{\prime} \mathrm{N}$ & $01^{\circ} 02.0^{\circ} \mathrm{E}$ & 2753 \\
\hline $644 \mathrm{~A}$ & $66^{\circ} 40.7 \mathrm{~N}$ & $04^{\circ} 34.6^{\circ} \mathrm{E}$ & 1227 \\
\hline $644 B$ & $66^{\circ} 40.7^{\circ} \mathrm{N}$ & $04^{\circ} 34.6^{\circ} \mathrm{E}$ & 1227 \\
\hline
\end{tabular}

from dominantly dextral to sinistral at $6.2 \mathrm{Ma}$ and back to dominant dextral at $2.3 \mathrm{Ma}$ are distinct markers. Coiling changes from dominantly dextral to dominantly sinistral coiled morphotypes of $N$. atlantica have been reported in many studies. At Leg 94 Sites 609-611 this change takes place between 6.5 and 7 Ma (Hooper and Weaver, 1987; Weaver and Clement, 1987). The second coiling change in $N$. atlantica from sinistral to dextral is a new observation found only in Hole 644A. This suggests a difference in last appearance date of $N$. atlantica dextral morphotype $(1.84 \mathrm{Ma})$ and last appearance date of $N$. atlantica sinistral morphotype below the base of Olduvai subchron ( 2.3 Ma). At Goban Spur Site 548 (Pujol and Duprat, 1985) and North Atlantic Sites 609-611 (Hooper and Weaver, 1987) the last occurrence level of $N$. atlantica sinistral is fixed below the Olduvai subchron.

\section{Neogloboquadrina continuosa (Blow, 1959). PI. 1, Figure 7}

The four-chambered $N$. continuosa with comma-shaped aperture ranges up to the early Pliocene and became extinct in the North Atlantic between 4.5 and 4.7 Ma (Hooper and Weaver, 1987; Weaver and Clement, 1987). In the Leg 104 samples $N$. continuosa occurs sporadically, but the last occurrence level is not younger than $4.7 \mathrm{Ma}$ according to the paleomagnetic time scale of Bleil (this volume).

\section{Neogloboquadrina dutertrei (d'Orbigny, 1839). PI. 1, Figures 1-3}

Five-chambered, heavily encrusted forms with aperture restricted to an umbilical position bordered by a thick lip can be distinguished from the form with an umbilical aperture flanked by a flap.

\section{Neogloboquadrina cf. dutertrei (d'Orbigny, 1839). PI. 2, Figures 8-9}

Five-chambered Neogloboquadrina morphotypes with an umbilical aperture occur together with $N$. pachyderma. They are smaller than the typical $N$. dutertrei. This morphotype is often referred to as pachyderma-dutertrei intergrade ( $p$ - $d$ intergrade) (Kipp, 1976).

Neogloboquadrina mayeri (Cushman and Ellisor, 1939). PI. 1, Figures 13-15

The curved suture on the spiral side between the last two chambers is typical for this species. The high arched aperture resembles Globorotalia partimlabiata (Ruggieri and Sprovieri,
1970), a Mediterranean species of the early to middle Miocene. The equatorial outline is less lobate than in N. acostaensis.

\section{Neogloboquadrina pachyderma (Ehrenberg, 1861).} PI. 2, Figures 1-7

This species shows a very wide morphological variation in the degree of test compactness, expressed through variations between circular or quadrangular outline, in chamber arrangement and chamber number, low or higher arched aperture, normal or encrusted wall texture, and in left or right coiling direction. At $1.7 \mathrm{Ma}$, in the latest Pliocene, abundant $N$. pachyderma in heavy encrusted sinistral enrolled morphotype appeared. In Quaternary assemblages this morphotype inhabits polar environments.

\section{Neogloboquadrina praehumerosa (Natori, 1976). PI. 1, Figures 4-5}

This species was proposed as a subspecies intermediate between $N$. acostaensis and $N$. humerosa in having only five chambers in the final whorl instead of the six or seven in N. humerosa and a more open umbilicus than $N$. acostaensis. The umbilicus is more extraumbilical than in $N$. dutertrei.

\section{Neogloboquadrina pseudopima (Blow, 1969)}

This species can be considered as a four-chambered $N$. praehumerosa with a closed umbilicus.

\section{Neogloboquadrina sp., aff. peripheroronda (Blow and Banner, 1966). Pl. 1, Figure 16}

This species appears sporadically together with $N$. mayeri. It is differentiated from $N$. mayeri by the umbilical restricted slitlike aperture bordered by a lip and from $F$. peripheroronda by a smaller diameter and having only five instead of six or seven chambers in the final whorl.

\section{Neogloboquadrina sp. 1. Pl. 1, Figure 8}

The observed right-coiling specimen is intermediate between $N$. nana (Bolli, 1957) and $N$. continuosa (Blow, 1957). The size and the quadrangular outline resembles $N$. nana, but the open comma-shaped aperture is more like $N$. continuosa.

\section{RESULTS}

\section{Site 642}

Because no major differences in the lithological succession of the Site 642 holes are evident, we describe the faunas of Holes $642 \mathrm{~A}$ through $642 \mathrm{C}$ as a single profile.

About $270 \mathrm{~m}$ of Pleistocene, Pliocene, and Miocene sediments were recovered containing variable amounts of planktonic foraminifers (Table 2-3, Figs. 2-3).

The upper parts of the sections are dominated by Neogloboquadrina pachyderma in its heavily encrusted sinistral enrolled morphotype. The sequence dominated by $N$. pachyderma sin. contains abundant foraminifers in its upper part (down to Sections 104-642B-6-2, $54 \mathrm{~cm}=40.96 \mathrm{mbsf}$ and 104-642C-5-3, $17 \mathrm{~cm}=36.04 \mathrm{mbsf}$ ) whereas the lower part (down to Sections $104-642 \mathrm{~B}-7-2,131 \mathrm{~cm}=50.11 \mathrm{mbsf}$ and $104-642 \mathrm{C}-6-4, \mathrm{CC}=$ $50.46 \mathrm{~cm}$ ) has a very low foraminifer content. Minor amounts of Globigerina bulloides, Globigerina quinqueloba, Neogloboquadrina pachyderma dextral enrolled morphotype and a fivechambered sinistral enrolled Neogloboquadrina cf. dutertrei are also recognized. In the fraction $>125 \mu \mathrm{m}$ we also find Globigerinita glutinata. These accessory species together account for about $1 \%$ of the fauna in the sediments of the $N$. pachyderma sin. zone, sometimes reaching amounts as high as $8 \%$. These percentages are much lower than the present distribution at the 
Table 2. Distribution of planktonic foraminifers in Hole 642A.

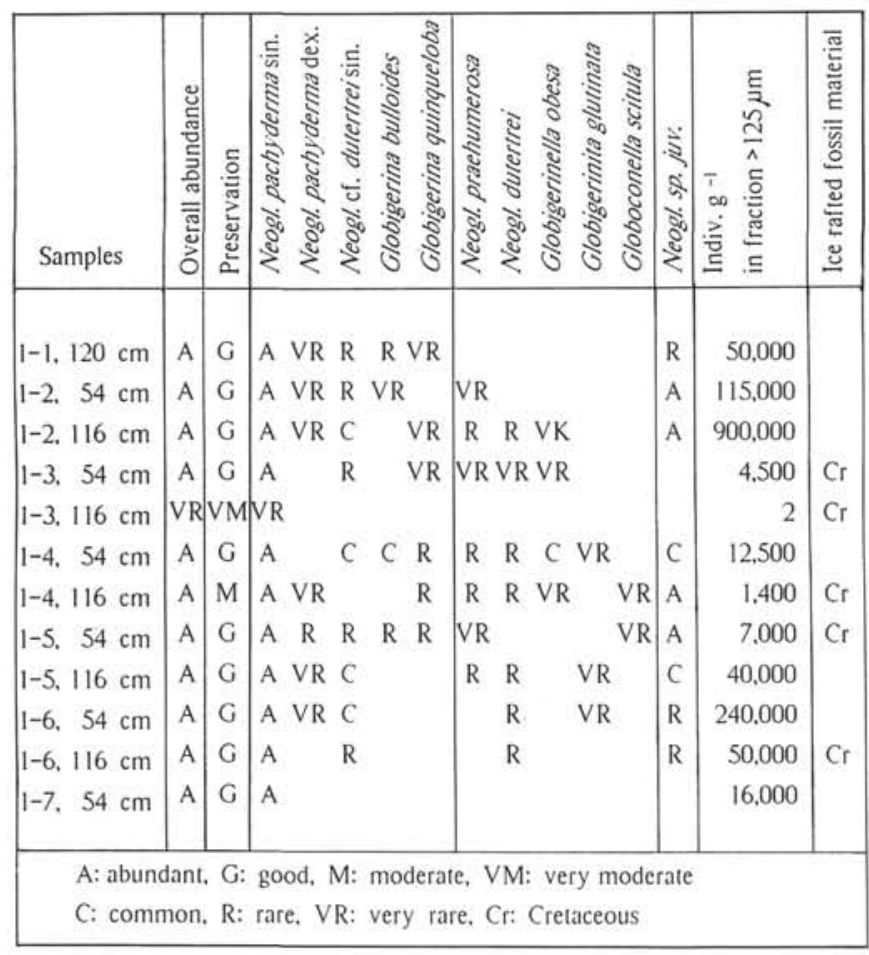

Vøring Plateau where $N$. pachyderma sin. only constitutes about $40 \%$ of the fauna (Johannessen, 1987).

The practically monospecific association of $N$. pachyderma sin. shows highly variable abundances (Fig. 4). Based on the interpretation of isotope stages and carbonate curves presented by Henrich (this volume) and Jansen et al. (this volume), the high planktonic foraminifer abundance peaks appear to correlate to odd isotopic stages 3 to 19 , e.g., interglacials. And there is sometimes a correlation between lower concentrations of planktonic foraminifers and well-defined dark lithologies. The dark layers consist of various deglaciation sediments, either deposited during the major transition from a glacial to an interglacial period or during an initial warming within a glacial period. Henrich (this volume) showed strong calcite dissolution patterns in these horizons and concluded that low carbonate content was caused by a combination of dissolution and lower carbonate productivity during deglaciation times.

Underlying the interval dominated by $N$. pachyderma is a barren interval down to $67.74 \mathrm{mbsf}$ in Hole 642B and down to $59.32 \mathrm{mbsf}$ in Hole $642 \mathrm{C}$. In correlation to paleomagnetic control (Bleil, this volume) the Pleistocene/Pliocene boundary lies in the barren sequences. Furthermore, comparing these sequences with the more complete sequences in Hole 644A, two zones of planktonic foraminifers defined there are not recognized at Site 642.

Beneath the barren interval is a section characterized by NeOgloboquadrina atlantica. A shift in coiling direction further subdivides this interval into an upper part characterized by sinistrally coiled specimens and a lower part where dextrally coiled $N$. atlantica is most typical. $N$. atlantica $\sin$. characterizes the interval 68.13 to $112.76 \mathrm{mbsf}$ in Hole $642 \mathrm{~B}$ and between 60.76 and $112.15 \mathrm{mbsf}$ in Hole $642 \mathrm{C}$. Dextral $N$. atlantica characterizes the intervals 124.85 to 143.66 mbsf in Hole $642 \mathrm{~B}$ and 123.04 to $138.33 \mathrm{mbsf}$ in Hole $642 \mathrm{C}$. The exact placement of the coiling change is difficult because it occurs across a barren interval.
We assume it occurred between 6 to $6.2 \mathrm{Ma}$. The fauna in the $N$. atlantica zone is at times relatively diverse, but is strongly dominated by species of the Neogloboquadrina lineages and by Globigerina bulloides.

The intervals from 146.66 to 160.27 mbsf in Hole 642B and 149.55 to 157.96 mbsf in Hole $642 \mathrm{C}$ are characterized by Neogloboquadrina acostaensis and other Neogloboquadrina taxa except for $N$. atlantica. The first occurrence date of $N$. acostaensis at the base of the interval is the marker for the base of the upper Miocene at about 10.2 Ma.

The last occurrence of Neogloboquadrina mayeri at 158.61 mbsf in Hole 642B and at 156.70 mbsf in Hole $642 \mathrm{C}$ is remarkable. N. acostaensis and N. Mayeri occur together in Hole 642B in a 1.6-m-thick interval and in Hole $642 \mathrm{C}$ in a sequence $1.26 \mathrm{~m}$ thick. Coring disturbance and/or bioturbation may be responsible for this observation; since $N$. mayeri is a species typically in lower and middle Miocene sequences. The interval characterized by $N$. mayeri also contains Neogloboquadrina continuosa and covers the section from 162.94 to $168.44 \mathrm{mbsf}$ in Hole 642B and from 157.96 to $159.31 \mathrm{mbsf}$ in Hole $642 \mathrm{C}$. At $163.27 \mathrm{mbsf}$ in Hole 642B, a single specimen of Neogloboquadrina sp. 1, aff. peripheroronda was observed. It is differentiated from Fohsella peripheroronda by having a smaller diameter and only five chambers in the final whorl. The LAD of $F$. peripheroronda is the middle part of the zone N10 at about $15 \mathrm{Ma}$.

Beneath 159.31 mbsf in Hole $642 \mathrm{C}$ the sediments are barren of planktonic foraminifers. The same situation is also found in Hole 642B except for a single occurrence of $N$. continuosa at $168.44 \mathrm{msbf}$, indicating middle Miocene age, and an observation of Globigerinoides trilobus at 199.11 mbsf. The FAD of Gls. trilobus is at the N4/N5 boundary in the early Miocene.

Hole 642D, which covers the interval 189 to $329.9 \mathrm{mbsf}$, is essentially barren of planktonic foraminifers except for a few samples which obviously contain downhole contamination. In these samples (104-642D-11-1, $121 \mathrm{~cm}$; -642D-11-2, $114 \mathrm{~cm}$; $-642 \mathrm{D}-12-1,49 \mathrm{~cm}$; and -642D-12-4, $72 \mathrm{~cm}$ ) we observe assemblages typical of the uppermost sediments at the site, characterized by encrusted morphotypes of N. pachyderma sin., Gl. quinqueloba, and $N$. cf. dutertrei.

During the shipboard study a number of the cataclastic sediments found in the dipping reflector sequence drilled at Hole $642 \mathrm{E}$ were examined. None of these contain any traces of planktonic foraminifers.

\section{Site 643}

A single hole was drilled at this site. In a manner analogous to Site 642 , the upper part of the hole is dominated by $N$. pachyderma sin., with an underlying interval characterized by $N$. atlantica. The two intervals are separated by a barren zone as at Site 642 (see Fig. 2).

The upper part of Hole 643A dominated by $N$. pachyderma sin., can be divided into an upper section with relatively abundant foraminifer content and an underlying interval with very low abundance. The fluctuating abundances of planktonic foraminifers (species per gram of sediment) appear to reflect glacial to interglacial variations, and if the time scale suggested by Henrich (this volume) is used, they correspond to isotope stages 1-21 (Fig. 6). The faunas in the upper part are almost monospecific $N$. pachyderma sin. assemblages with a few scattered specimens of $N$. pachyderma dex., Gl. bulloides and Gl. quinqueloba. Down to $45 \mathrm{mbsf}$, ice-rafted fossils, mostly prisms of Inoceramus, were observed.

The last occurrence of $N$. atlantica is found at $54.06 \mathrm{mbsf}$ and their first occurrence is at $86.20 \mathrm{mbsf}$. As at Site 642 , there is only one prominent change in the coiling direction of $N$. 
Table 3. Zonation of planktonic foraminifers in Holes 642A-642E.

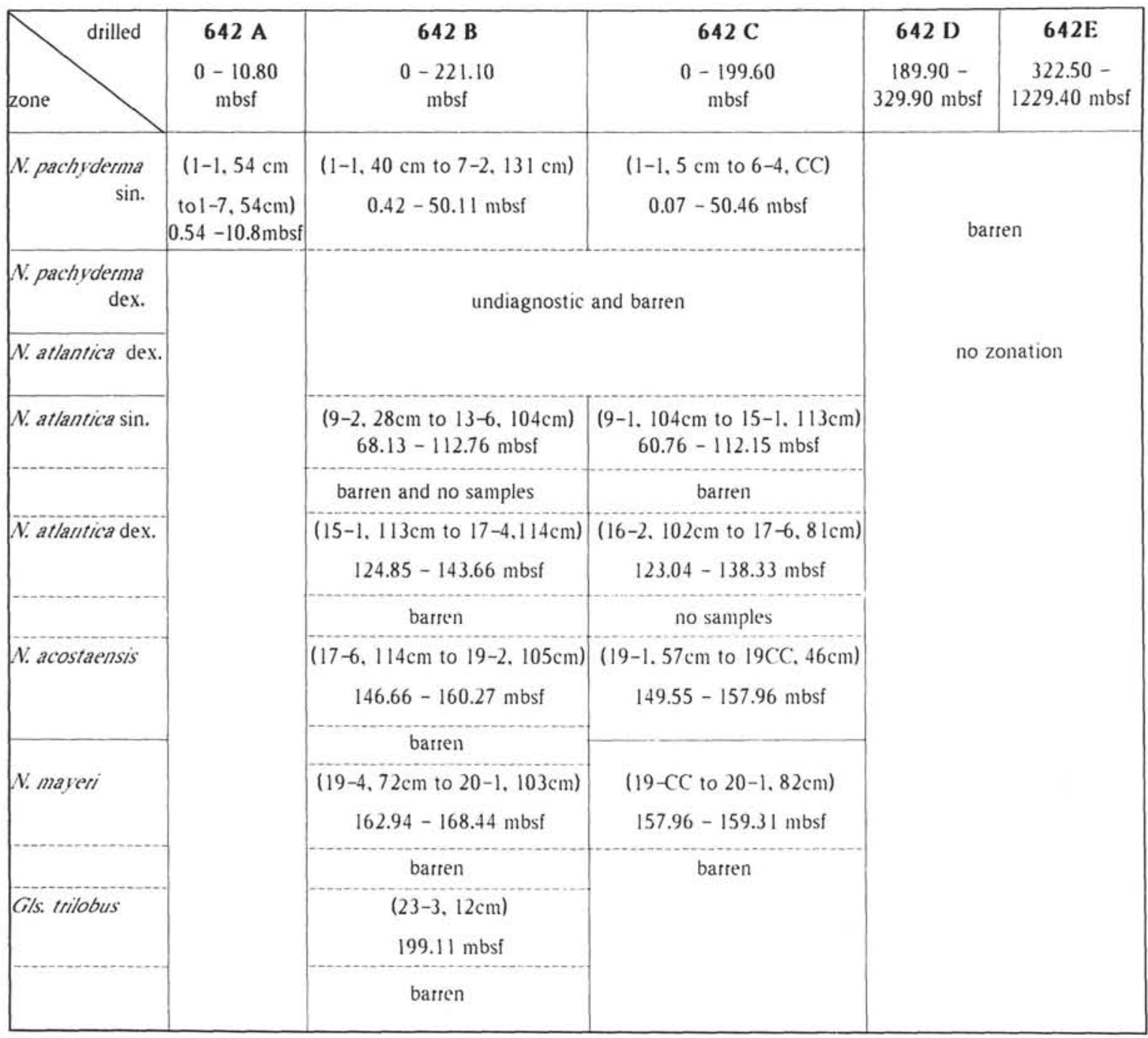

atlantica within this interval and the division appears across a barren interval. The upper part, characterized by sinistral forms, is only $5.36 \mathrm{~m}$ thick, indicating that parts of the record are missing when compared with Site 642 . The last occurrence of dextral coiling $N$. atlantica is at $72.20 \mathrm{mbsf}$. The $N$. atlantica interval is dominated by this taxa and by $\mathrm{Gl}$. bulloides. The rare appearances of $N$. pachyderma down to 83.20 mbsf is remarkably different from Site 642 , where this morphotype only appears much higher in the section.

Beneath the $N$. atlantica interval is a barren zone between 87.70 and 97.20 mbsf. In the sequence between 98.70 to 99.96 mbsf a few $N$. acostaensis and $N$. continuosa are present, correlating this sequence with the interval characterized by $N$. acostaensis at Site 642 . However, this interval is more poorly represented at Site 643 than at Site 642 . The underlying sediments down to $141.68 \mathrm{mbsf}$ are barren of planktonic foraminifers. At this level $N$. mayeri appears together with a species intermediate between Neogloquadrina nana and $N$. continuosa, and at 147.68 mbsf a single specimen of $\mathrm{Gl}$. quinqueloba is observed.

The remainder of the hole is barren of planktonic foraminifers except for a few scattered samples in the deeper parts of the section. At 409.70 and $419.40 \mathrm{mbsf}$ small and poorly preserved globigerinids are observed. The species identified are Globigerina anguliofficinalis, Subbotina linaperta, and Neogloboquad- rina angiporoides, suggesting the presence of Zones P16 to P19 in the Oligocene. At 496.70 and 535.30 mbsf we observe small and poorly preserved specimens of Globigerina officinalis and $S$. linaperta, indicating a middle to late Eocene age (P13).

\section{Site 644}

Two holes were drilled at Site 644. Planktonic foraminifers were analyzed in detail only in Hole 644A sediments (Fig. 7). Hole 644A penetrated Pleistocene and upper Pliocene sediments, stopping at 252.80 mbsf in the Gauss normal event (Bleil, this volume). Down to $168.30 \mathrm{mbsf} N$. pachyderma sin. dominates with fluctuating abundances (Fig. 8). Also in this hole the high abundances appear to correlate to interglacials. Downhole to 178.00 mbsf, sparse faunas with $N$. pachyderma dextral, Globoconella inflata, Gl. bulloides, and Gl. quinqueloba are observed. Beneath 178.00 mbsf a section characterized by $N$. atlantica occurs. Globoconella puncticulata together with Globoconella inflata below 180.00 mbsf characterize the upper Pliocene.

In contrast to Sites 642 and 643, dextral coiling $N$. atlantica occurs at shallower depth levels in Hole 644A than $N$. atlantica sin. They are observed from 178.40 to $211.52 \mathrm{mbsf}$, whereas sinistral coiling $N$. atlantica occurred only below $211.92 \mathrm{mbsf}$. The sequences dominated by $N$. pachyderma dex. together with the underlying sediments with $N$. atlantica dex., indicate in 


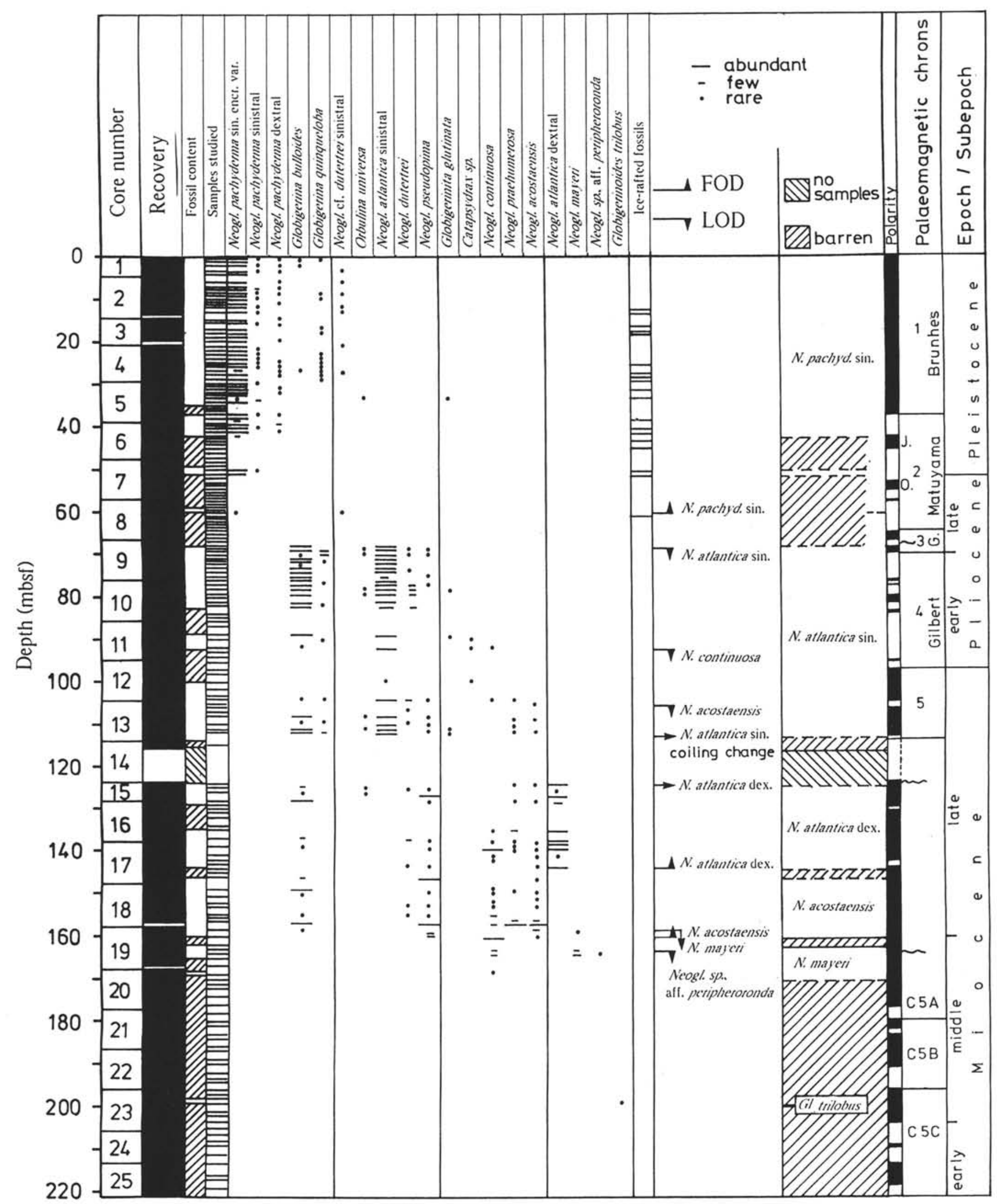

Figure 2. Distribution of planktonic foraminifers in Hole 642B. 


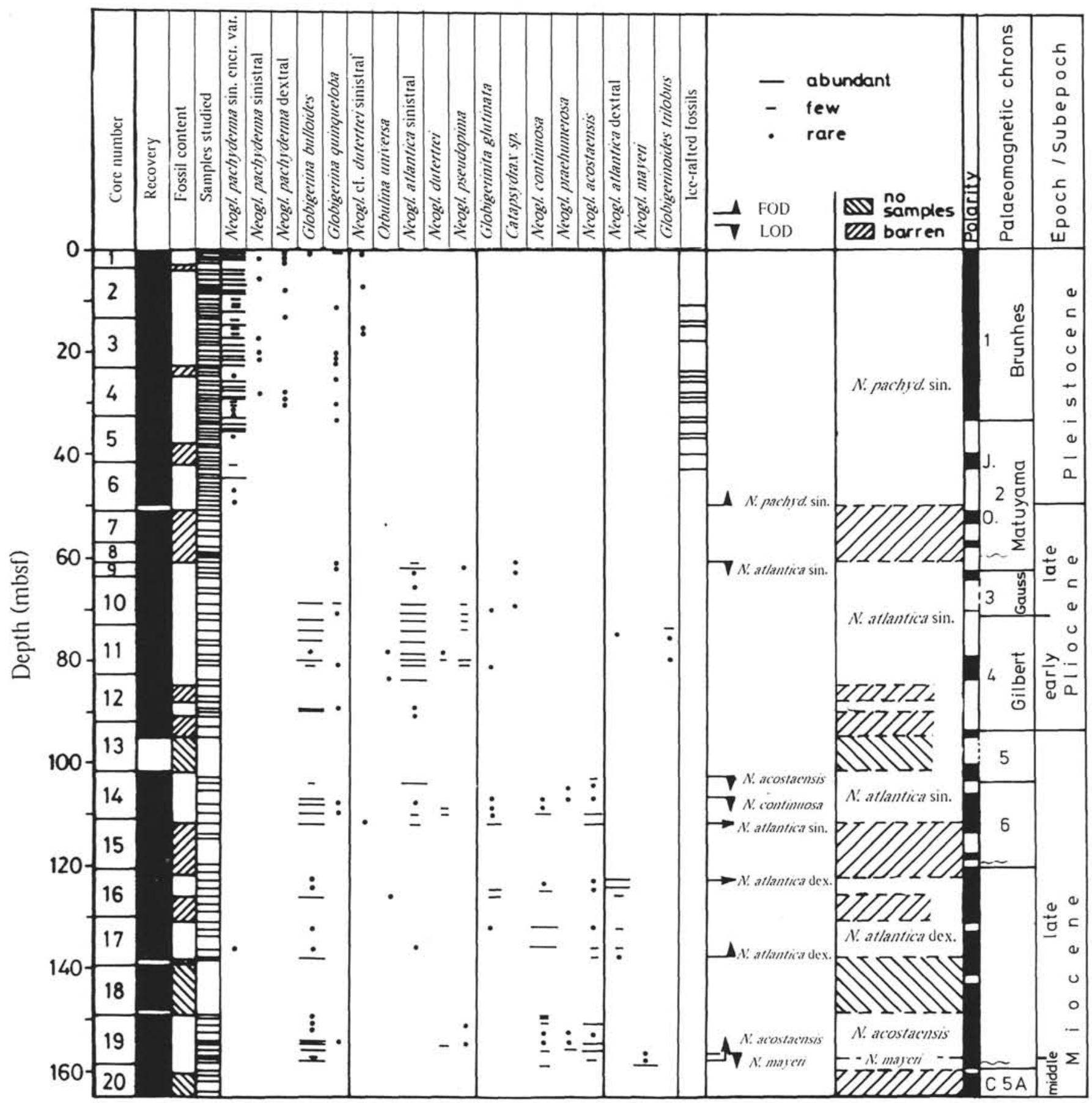

Figure 3. Distribution of planktonic foraminifers in Hole $642 \mathrm{C}$.

Hole 644A a more complete sequence in upper Pliocene than in the other holes of Site 642 and Site 643.

\section{ZONATION}

Except for a few cases, it is not feasible to use standard zonation schemes to subdivide the Leg 104 records. This is due to dissolution, barren intervals, and low-diversity faunas. The stratigraphically useful taxa belong to the Neogloboquadrina lineages which dominate the faunas either because they are more solution resistent and/or they thrive better at high latitudes.

Some Neogloboquadrina events appear to correlate to other North Atlantic biostratigraphic events and seem to be isochro- nous, whereas other events are not isochronous and appear to shift in time with latitude. Better paleomagnetic control is needed to sort out some of the discrepancies and to improve the stratigraphic usefulness of the Neogloboquadrina events of the late Neogene. In the following we propose a local zonation based on Neogloboquadrina events. The zonal division of the individual holes is shown in Figures 2, 3, 5, and 7. In Figure 9 we attempt to correlate the zones to the standard Neogene zonation and to recently established North Atlantic zones (Weaver 1987; Weaver and Clement 1986, 1987). As can be seen in these figures, the stratigraphic resolution of the zonation is sometimes very poor due to the long-ranging nature of the assemblages. 


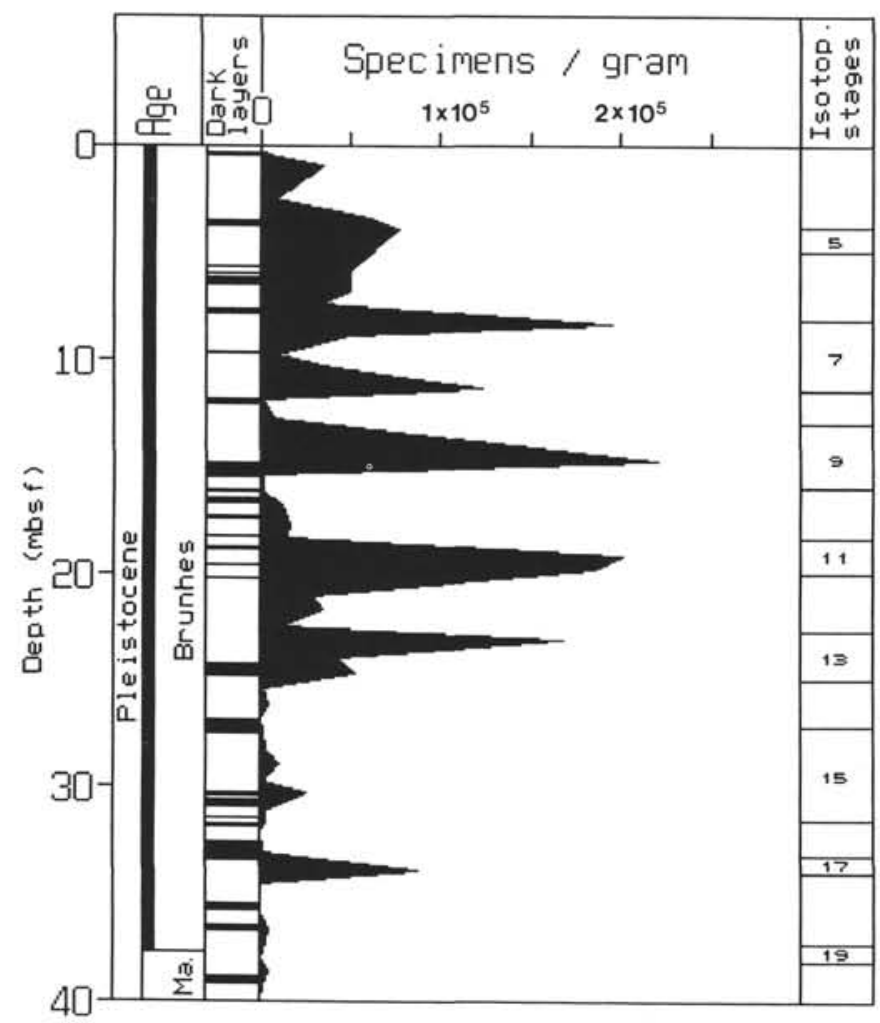

Figure 4. Abundances of planktonic foraminifers and correlation to dark lithologies and isotope stages of the Quaternary, Hole 642B.

\section{Miocene}

It was not possible to subdivide the lower Miocene because most samples of this age were barren of planktonic foraminifers. Only few scattered samples give indications of an early Miocene age. Appearance of Gls. trilobus at $199.11 \mathrm{mbsf}$ in Hole $642 \mathrm{~B}$ indicates a younger age than N4/N5 $(<20 \mathrm{Ma})$. Specimens of $N$. mayeri and a transitional $N$. nana $-N$. continuosa found at $141.68 \mathrm{mbsf}$ in Hole 643A may indicate early Miocene Zones N3-N6.

According to Kennett and Srinivasan (1983; text Fig. 4), in temperate regions the middle Miocene is subdivided into the $\mathrm{Or}$ bulina suturalis-, the Globorotalia (F.) peripheroronda/peripheroacuta- and the Globorotalia mayeri- Zones. In the Leg 104 records such a subdivision is impossible. A single specimen of $N$. sp. aff. peripheroronda together with $N$. mayeri and $N$. continuosa at $163.27 \mathrm{mbsf}$ in Hole 642B might be taken as an indication of the Gl. peripheroronda Zone. This species became extinct in the middle part of $\mathrm{N} 10$ at about $15 \mathrm{Ma}$ according to Kennett and Srinivasan (1983), and at $16 \mathrm{Ma}$ according to Bolli and Saunders (1985). If correct, this would place a large hiatus between this level and the first occurrence of $N$. acostaensis at $160.27 \mathrm{mbsf}$ in Hole 642B. However, with only a single observation and a taxon which differs from the typical Fohsella peripheroronda, we prefer to regard this evidence and place the hiatus between the $N$. acostaensis Zone and the $N$. mayeri Zone.

In the high-latitude North Atlantic, Weaver (1987) subdivided the upper Miocene into the $N$. atlantica $(\mathrm{d}) / N$. acostaensis Zone and the overlying Globoconella conomiocea Zone. The change in coiling direction from dextral to sinistral $N$. atlantica was used as a criterion to distinguish the zones. By direct correlation with paleomagnetic results. Hooper and Weaver (1986) and Weaver and Clement (1987) dated the coiling change to 6.5-7 Ma. This is significantly older than earlier estimates given by Berggren (1972) and Poore (1979), who used the change to define the Miocene/Pliocene boundary (5.2 Ma). Like the North Atlantic record, the Leg 104 results allow a subdivision of upper Miocene into a $N$. acostaensis Zone overlain by $N$. atlanica dex. Zone and lower parts of the N. atlantica sin. Zone. Globoconella conomiocea is not observed and cannot be used as a zonal marker. The $N$. acostaensis Zone is defined as the interval from the FAD of $N$. acostaensis to the FAD of $N$. atlantica. The base of the zone defines the base of the upper Miocene (Kennett and Srinivasan 1983). Small specimens of $N$. mayeri in the deepest parts of the zone are remarkable and indicate disturbations and/or bioturbations between the middle and the upper Miocene at Site 642 . At Site 643 the $N$. acostaensis Zone only spans $2 \mathrm{~m}$, and the deeper part appears to be missing, indicating a hiatus of longer duration than at Site 642 .

The following $N$. atlantica superzone is defined by the range of the zonal marker, spanning parts of the upper Miocene and reaching into the uppermost Pliocene. The change in coiling direction defines a lower $N$. atlantica dex. Zone, the overlying $N$. atlantica $\sin$. Zone and the upper $N$. atlantica dex. Zone (defined only at Hole 644A). Unfortunately at both Sites 642 and 643 , a barren interval appears at the lower boundary of the $N$. atlantica dex.- $N$. atlantica sin. Zone, thus preventing exact definition of the boundary. We assume it lies between 6 and $6.2 \mathrm{Ma}$ in Hole 642B. If so, this date is in good accordance with Weaver and Clement (1987), dating the coiling change dextral to sinistral N. atlantica in Sites 610 and 611 between 6 and $7 \mathrm{Ma}$. The Miocene/Pliocene boundary lies within the $N$. atlantica sin. Zone and cannot be defined by planktonic foraminifers in Leg 104 sites.

\section{Pliocene}

Most of the Pliocene age is occupied by the $N$. atlantica sin. Zone. In Hole 644A the N. atlantica sin. Zone is overlain by an upper $N$. atlantica dex. Zone, a $N$. pachyderma dex. Zone, and a small part of the $N$. pachyderma sin. Zone. These zonations are only documented in Hole 644A. According to the paleomagnetic reversals in this hole (Bleil, this volume), the base of upper $N$. atlantica dex. Zone is $2.30 \mathrm{Ma}$, the base of $N$. pachyderma dex. Zone is $1.84 \mathrm{Ma}$, and the base of N. pachyderma sin. Zone is $1.70 \mathrm{Ma}$. In contrast, at Sites 642 only barren intervals lie between the upper $N$. atlantica sin. Zone and the $N$. pachyderma $\sin$. Zone. By comparison with paleomagnetic data, the top of Pliocene (1.6 Ma) lies in the deepest parts of the $N$. pachyderma sin. Zone.

In lower Pliocene sediments, $N$. atlantica sin. and $\mathrm{Gl}$. bulloides strongly dominate the assemblages. At Site 644 the upper Pliocene is documented by rare Globoconella puncticulata and Globoconella inflata. The uppermost Pliocene sediments, belonging to the glacial sequence that started at about $2.56 \mathrm{Ma}$ (Henrich, this volume; Jansen et al., this volume), are barren in the lower part and contain sparse encrusted $N$. pachyderma sin. in the higher parts. The first abundant occurrences of N. pachyderma sin. encrusted morphotype are found at Site 644 just above the Olduvai event at $1.70 \mathrm{Ma}$, which is in good agreement with North Atlantic data (Hooper and Weaver, 1986; Raymo et al. 1987). However, rare occurrences of this morphotype as deep as the $N$. atlantica dex. Zone in Hole 643A indicate that this event might not be an isochronous stratigraphic marker over large distances at high northern latitudes. That the top of the Pliocene lies within the deepest parts of the N. pachyderma sin. Zone is in contrast to Poore and Berggren (1975), who used the LAD of N. atlantica to define the Pliocene/Pleistocene boundary. Recently Pujol and Duprat (1985) and Hooper and Weaver 


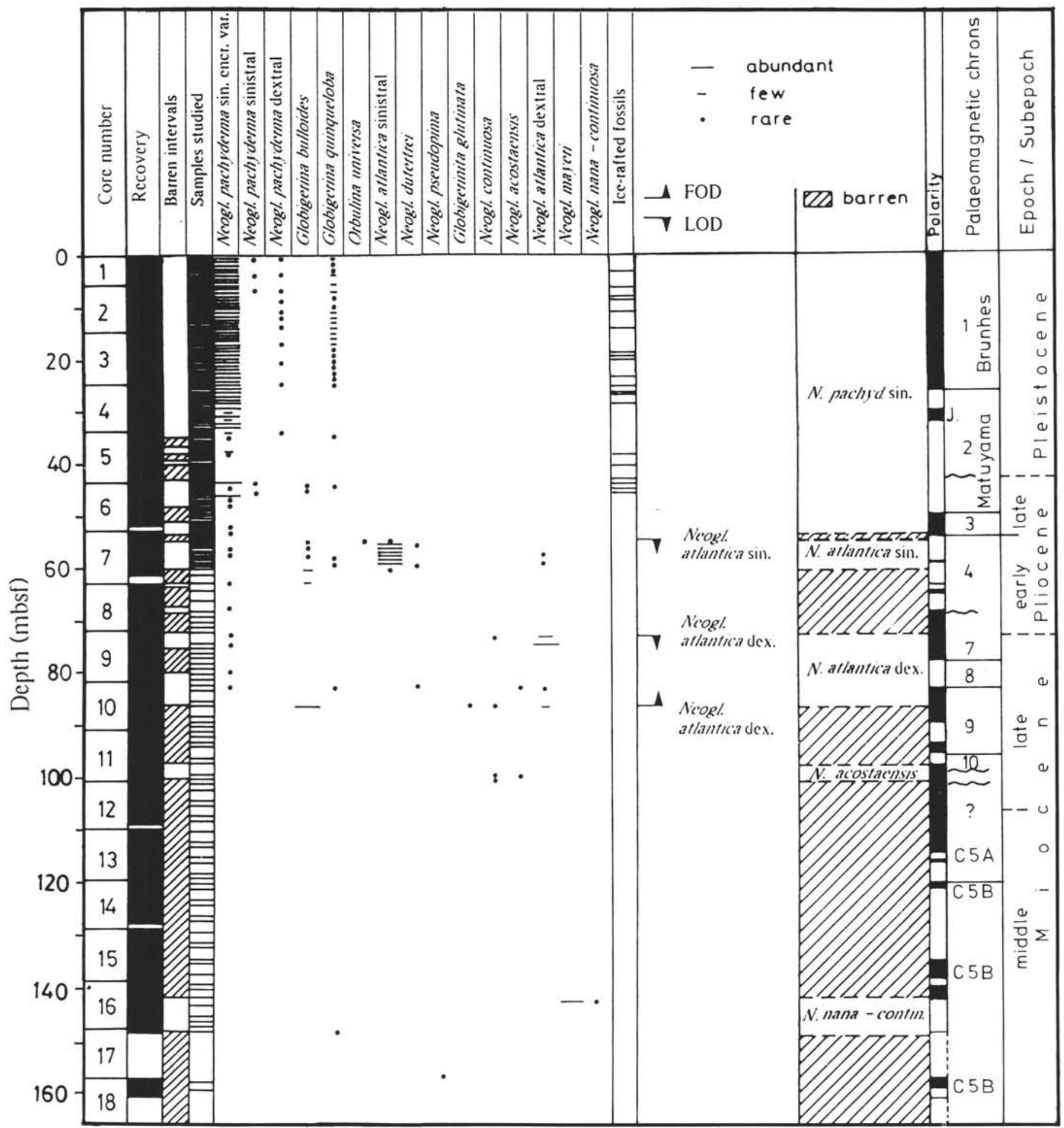

Figure 5. Distribution of planktonic foraminifers in Hole 643A.

(1986) dated the LAD of $N$. atlantica as being older than the Olduvai at about $2.3 \mathrm{Ma}$ by means of correlation with magnetostratigraphy.

\section{Quaternary}

The $N$. pachyderma sin. Zone spans the entire Quaternary. Nearly monospecific assemblages of sinistral encrusted $N$. pachyderma characterize the Quaternary. In the Matuyama section, in sediments older than about $0.78 \mathrm{Ma}$ at Site 643 and $0.73 \mathrm{Ma}$ at Site 642 , planktonic foraminifers were mostly removed by disso- lution (Henrich, this volume), whereas in Hole 644A the whole Quaternary sequence contains foraminifers. The abundance of other species is generally low. Subpolar planktonic foraminifers appear to be higher in the Quaternary of Hole 644A and in interglacial times especially in isotope stage 11 . The practically monospecific association of $N$. pachyderma sin. shows highly variable abundances (Figs, 4, 6, 8). High planktonic foraminifer content appears to correlate to odd isotopic stages e.g., interglacials. This may help to subdivide Quaternary sediments in more detail for future work. 


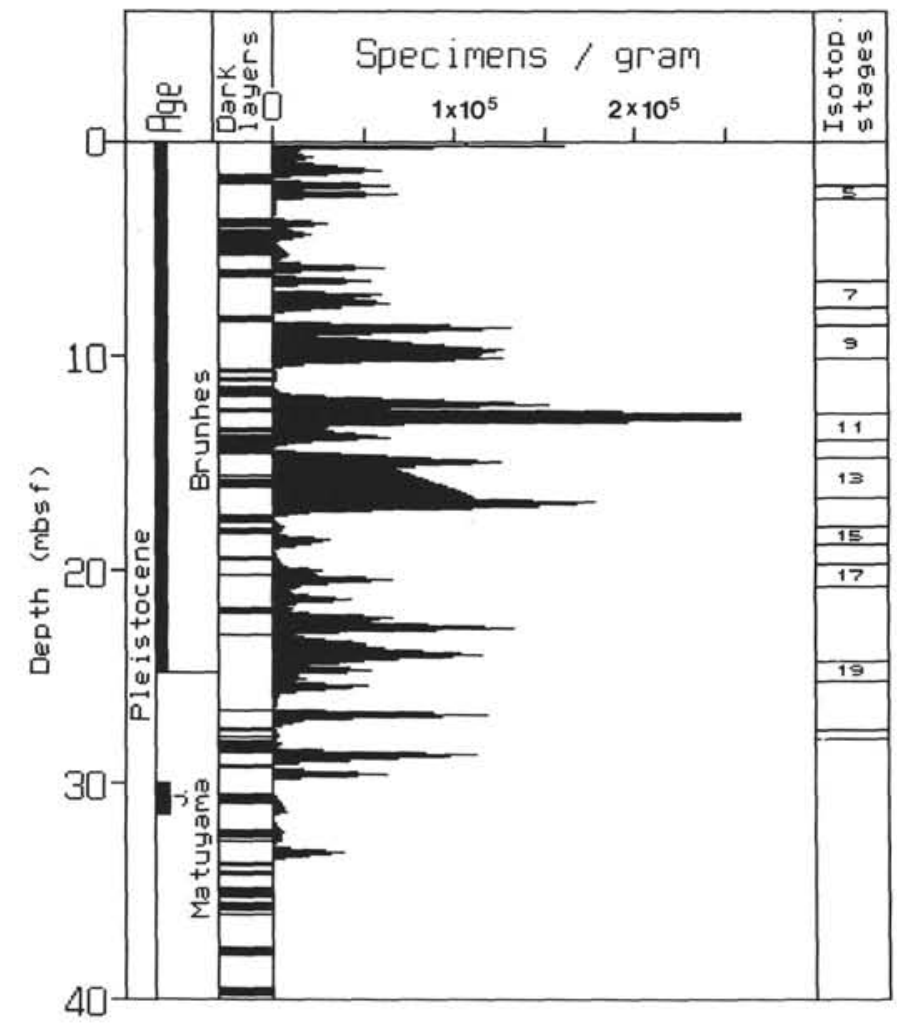

Figure 6. Abundances of planktonic foraminifers and correlation to dark lithologies and isotope stages of the Quaternary of Hole 643A.

\section{COMPARISON WITH LEG 104 INITIAL REPORTS ZONATION}

An informal and preliminary local zonation NSPF (Norwegian Sea Planktonic Foraminifera) Zones 1-6 was used for Leg 104 Initial Reports. Subsequently, studies have provided more details, and a finer taxonomic distinction between some of the Neogloboquadrina species has been established.

The NSPF1 and NSPF2 Zones (Eldholm, Thiede, Taylor, et al., 1987) refer to the Eocene and Oligocene sections at Hole 643A (Fig. 10). As these only contain sporadic occurrences of poorly preserved specimens, we omit any zonal assignment at this point. The discovery of the last occurrence of $N$. mayeri provided the opportunity to subdivide the lower part of the NSPF3 Zone (Eldholm, Thiede, Taylor, et al., 1987) into the $N$. mayeri and N. acostaensis Zones. The top of the NSPF3 was defined by the LOD of $N$. continuosa. However, because the extinction of this species appears at different levels in the two holes at Site 642 , we decided to use the range of $N$. atlantica to define the interval previously covered by the upper part of NSPF3 and NSPF4. NSPF5 was a zone covering a short interval between the LOD of $N$. atlantica sin. and the FOD of $N$. pachyderma sin. encrusted variety. Subsequent work has moved the LOD of $N$. atlantica upward, thus in part filling the gap that defined Zone NSPF5. The remainder of the gap between the last occurrence of $N$. atlantica sin. and the bottom of the N. pachyderma sin. Zone consists of a barren interval at Sites 642 and 643, whereas in Hole 644A the upper $N$. atlantica dex. Zone and the $N$. pachyderma dex. Zone filled the gap. Zone NSPF6 of Eldholm, Thiede, Taylor, et al., (1987) is equivalent to the $N$. pachyderma sin. Zone of this paper.

\section{PLANKTONIC FORAMINIFER ZONATION AND THEIR PALEOMAGNETIC CONTROL}

According to paleomagnetic control (Bleil, this volume) we are able to date exactly the zones defined here:

- 1.70 Ma base of N. pachyderma sin. Zone

- 1.84 Ma base of $N$. pachyderma dex. Zone

$-2.30 \mathrm{Ma}$ base of upper $N$. atlantica dex. Zone

- 6.20 Ma base of $N$. atlantica sin. Zone

- $8.90 \mathrm{Ma}$ base of lower $N$. atlantica dex. Zone

$<10.20$ Ma base of $N$. acostaensis Zone

$>10.20$ Ma top of $N$. mayeri Zone.

\section{CORRELATION}

In Figure 9 are depicted different zonation schemes on the time scale of Berggren et al.(1985). The standard low-latitude zonation of Blow (1969) is shown together with the zonation scheme of Berggren $(1973,1977)$ and Berggren et al. (1983, 1985). Also shown are the schemes proposed for the cool temperate to high-latitude North Atlantic by Weaver (1987) and Weaver and Clement $(1986,1987)$. Correlation of the Leg 104 zones into this framework is proposed based on the FOD's and LOD's of single Neogloboquadrina taxa and the paleomagnetic record of Bleil (this volume). As is evident from this compilation, the highly dissolved and barren intervals that bracket zonal boundaries, together with low species diversity, produce severe restrictions on the resolution of planktonic foraminifer biostratigraphy on the Vøring Plateau.

\section{PALEOENVIRONMENTS}

The barren intervals and the low diversity reduce the resolution of the planktonic foraminifer stratigraphy and place constraints on the environmental interpretation. The appearance of the abundant planktonic foraminifer associations in the middle Miocene suggest a major oceanographic change at that time, which enhanced carbonate preservation and increased the depth of the calcite lysocline. A possible cause for this was the establishment of stronger and more continuous water exchange with the North Atlantic following the deepening of the Greenland-Scotland passage during the middle Miocene (Thiede and Eldholm, 1983). However, during the late Miocene and the Pliocene there were also extensive intervals of no carbonate deposition and strong dissolution, pointing to an unstable situation. This variability is clearly shown in the distribution charts. The low diversity probably implies fairly cool and restricted environments during the whole period prior to the glacial onset at $2.56 \mathrm{Ma}$. The diversity was relatively high in the $N$. acostaensis Zone and lower $N$. atlantica dex. Zone. However, the richest faunas in terms of foraminifer abundance are found in the $N$. atlantica sin. Zone in the uppermost Miocene and lower Pliocene. Also of importance is the strong variance in species composition, especially variations in dominance between $\mathrm{Gl}$. bulloides and $N$. atlantica $\sin$. (Fig. 11). This variability probably reflects variations in sea-surface temperature and surface ocean circulation. Detailed studies of the upper Neogene sediments from Leg 94 sites indicate that $N$. atlantica has a stronger affinity to cooler temperatures than do Gl. bulloides (Raymo et al., 1987). These variations appear to be of potential importance for future, more detailed studies of the climatic evolution during the preglacial period in the Norwegian Sea.

The strong dissolution during the first part of the glacial interval (2.56-c. 1.2 Ma) at Sites 642 and 643 is interpreted to be a result of an oceanic regime with a low and restricted inflow of 


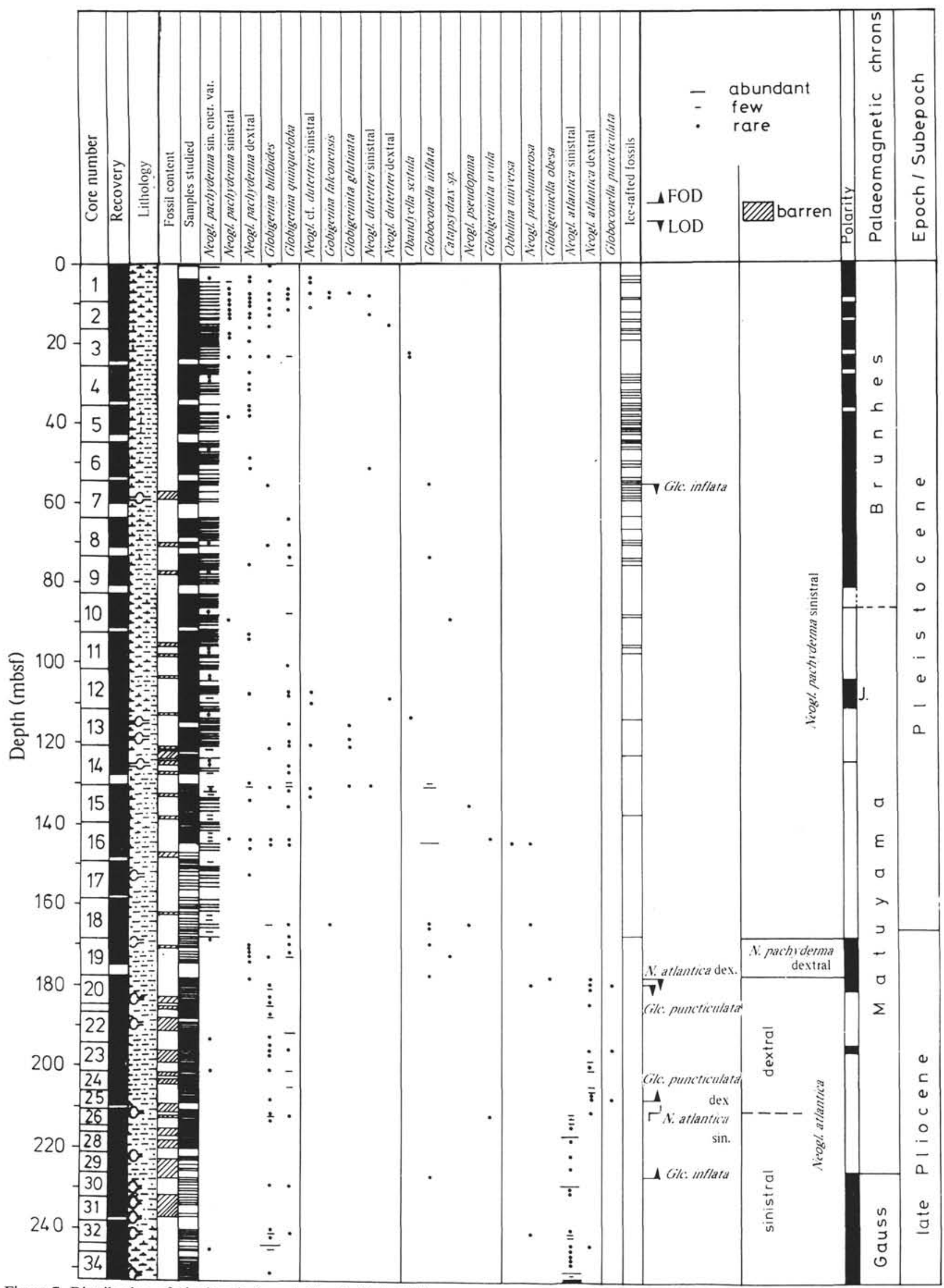

Figure 7. Distribution of planktonic foraminifers in Hole 644A. 


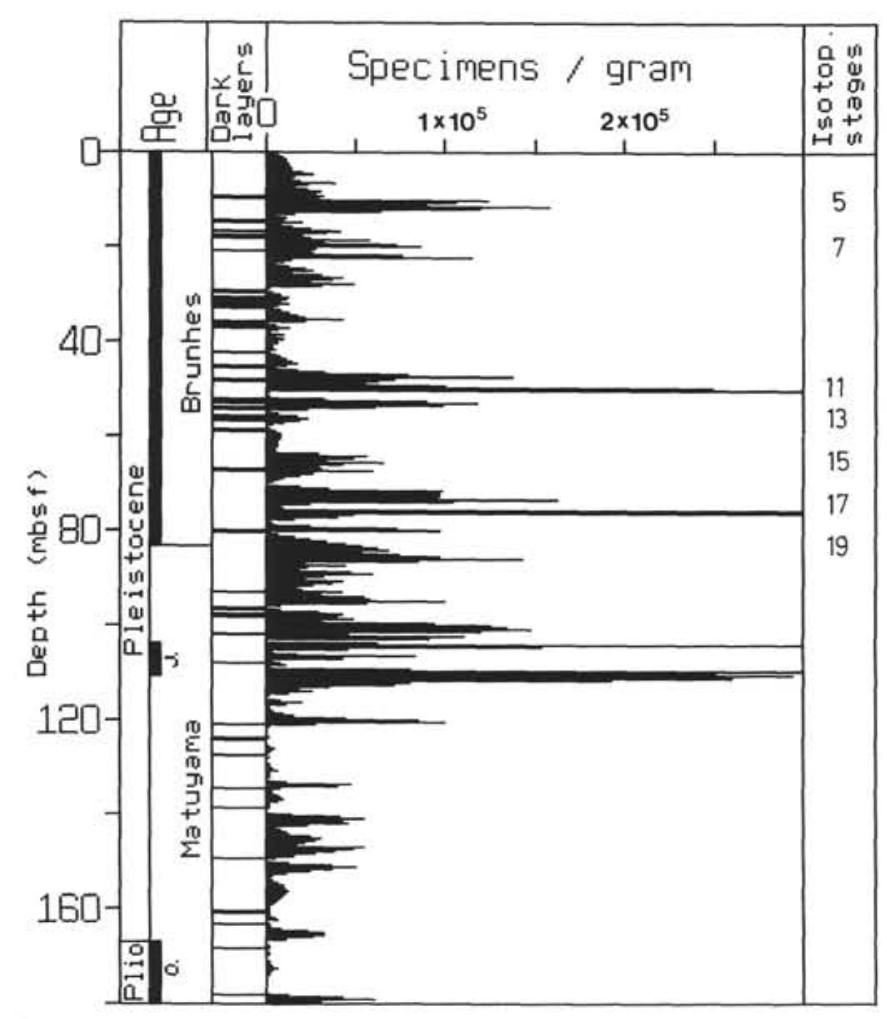

Figure 8. Abundances of planktonic foraminifers and correlation to dark lithology stages of the Pleistocene and Pliocene in Hole 644A. The isotopic stages are only interpolated.

temperate Atlantic waters and a climatic regime showing less variation than in the later parts of the Quaternary (Henrich, this volume; Jansen et al., this volume). Although peak interglacials are relatively short-lived, and thus might have been missed by our sample spacing, both the results from the detailed study at Site 643 and stable isotope analysis at Site 644 (Jansen and Slettemark, unpublished data) indicate that warm-water influx into the Norwegian Sea during interglacials is a young and rather seldomly occurring feature. The first indications of subpolar water masses during the glacial interval is seen at about $0.9 \mathrm{Ma}$, and only in a very few samples do we observe significant amounts of subpolar fauna suggestive of temperate surface waters over the Vøring Plateau. Although the glacial episodes probably were more severe during the Brunhes time $(0-0.73 \mathrm{Ma})$ (Jansen et a1., this volume), the interglacials became warmer than those of the preceeding period. Despite this warming, the interglacials throughout the late Pliocene and the Quaternary were only short episodes in a long glacial situation.

\section{CONCLUSIONS}

The results of the planktonic foraminifer analysis of Holes $642 \mathrm{~A}-642 \mathrm{C}, 643 \mathrm{~A}$, and $644 \mathrm{~A}$ enable us to establish a local biozonation from the middle Miocene to Recent on the Vøring Plateau. A long-ranging zonation with intercalated barren horizons can be established based on different Neogloboquadrina taxa. Some datum levels can be correlated with established North Atlantic zonations.

\section{ACKNOWLEDGMENTS}

We thank A. Freiwald, M. Weinelt, C. Wieger, B. Rippe, U. Schuldt, and R. Reimann (all Kiel, FRG) for technical assistance. For the helpful critical review we thank R. Corfield, G. Keller, and E. Taylor. This study was supported by grants from the German Research Foundation (DFG) and the Norwegian Research Council for Science and the Humanities (NAVF).

\section{REFERENCES}

Berggren, W. A.,1972. Cenozoic biostratigraphy and paleobiogeography of the North Atlantic. In Laughton, A. S., Berggren, W. A. et al., Init. Repts. DSDP, 12: Washington (U.S. Govt. Printing Office), 965-1001.

Berggren, W. A., 1973. The Pliocene time scale: Calibration of planktonic foraminiferal and calcareous nannoplankton zones. Nature, 243:391-397.

Berggren, W. A.,1977. Late Neogene planktonic foraminiferal biostratigraphy of the Rio Grande Rise (South Atlantic). Mar. Micropaleontol., 2:265-313.

Berggren, W. A., Aubry, M. P., and Hamilton, N., 1983. Neogene magnetostratigraphy of Deep Sea Drilling Project, Site 516 (Rio Grande Rise (South Atlantic). In Barker, P.F., Carlson, R., et al., Init. Repts. DSDP, 72: Washington (U.S. Govt. Printing Office), 675-713.

Berggren, W. A., Kent, D. V., Flynn, J.J., and van Couvering, J., 1985. Cenozoic geochronology. Geol. Soc. Am. Bull., 96:1407-1418.

Blow, W.H., 1969. Late middle Eocene to recent planktonic foraminiferal biostratigraphy. In Brönnimann, P., and Renz, H.H., (Eds.), Proc. Internatl. Conf. Plankt. Microfossils, 1st (Vol.1): Leiden (E. D. Brill), 199-421.

Bolli, H. M., 1966. Zonation of Cretaceous to Pliocene marine sediments based on planktonic foraminifera. Bol. Inf. Asoc. Venez. Geol. Min. Pet., 9:3-32.

Bolli, H. M., 1986. Evolutionary trends in planktic foraminifera from Early Cretaceous to Recent, with special emphasis on selected Tertiary lineages. Bull. Cent. Rech. Explor. Prod. Elf-Aquitaine, 10: 565-577.

Bolli, H. M., and Saunders, J. B., 1985. Oligocene to Holocene low latitude planktic foraminifera. In Bolli, H. M., Saunders, J. B., and Perch-Nielsen, K. (Eds.), Plankton Stratigraphy: Cambridge (Cambridge University Press), 155-262.

Eldholm, O., Thiede, J., Taylor, E., et al., 1987. Proc. ODP, Init. Repts., 104: College Station, TX (Ocean Drilling Program).

Hooper, P. W. P., and Weaver, P. P. E., 1987. Late Neogene species of the genus Neogloboquadrina Bandy, Frerichs and Vincent in the North Atlantic: a biostratigraphic, paleoceanographic and phylogenetic review. In Hart, M. B., (Ed.), Micropaleontology of carbonate environments: Chichester, U.K. (Ellis Horwood Limited), 21-43.

Johannessen, T., 1987. Faunasammensetning, taxonomi og stabil isotopgeokjemi i resente planktoniske foraminiferer fra Norskehavet, Islandshavet og Nord-Atlanteren. [Unpubl. Cand. Sci. thesis], Univ. of Bergen, Norway.

Kennett, J. P., and Srinivasan, M. S., 1983. Neogene planktonic foraminifera. A phylogenetic Atlas: Stroudsburg (Hutchinson Ross Publishing Company).

Kipp, N. G., 1976. New transfer function for estimating past seasurface conditions from sea-bed distribution of planktonic foraminiferal assemblages in the North Atlantic. Geol. Soc. Am. Mem., 145:3-41.

Poore, R. Z., 1979. Oligocene through Quaternary planktonic foraminiferal biostratigraphy of the North Atlantic: DSDP Leg 49. In Luydendyk, B. P., Cann, J. R., et al., Init. Repts. DSDP, 49: Washington (U.S. Govt. Printing Office), 447-517.

Poore, R. Z., and Berggren, W. A., 1975. Late Cenozoic planktonic foraminiferal biostratigraphy and paleoclimatology of Hatton-Rockall Basin; DSDP Site 116. J. Foram. Res., 5:270-293.

Pujol, C., and Duprat, J., 1985. Quaternary and Pliocene planktonic foraminifers of the northeastern Atlantic (Goban Spur), DSDP Leg 80. In Graciansky, P. C. de, Poag, C. W., et al., Init. Repts. DSDP, 80, Pt. 2: Washington (U.S. Govt. Printing Office), 683-723.

Raymo, M. E., Ruddiman, W. F., and Clement, B. M., 1987. PliocenePleistocene paleoceanography of the North Atlantic at Deep Sea Drilling Project Site 609. In Ruddiman, W. F., Kidd. R. B., Thomas, E., et al., Init. Repts. DSDP, 94, Pt. 2: Washington (U.S. Govt. Printing Office), 895-901.

Thiede, J., and Eldholm, O., 1983. Speculations about the paleodepth of the Greenland-Scotland Ridge during the Mesozoic and Cenozoic 
times. In Bott, M. H. P., et al. (Eds.), Structure and development of the Greenland-Scotland Ridge: New York (Plenum Press), 445-456.

Weaver, P. P. E., 1987. Late Miocene to Recent planktonic foraminifers from the North Atlantic: Deep Sea Drilling Project Leg 94. In Ruddiman, W. F., Kidd, R. B., Thomas, E., et al., Init. Repts. DSDP, 94, Pt. 2: Washington (U.S. Govt. Printing Office), 703-727.

Weaver, P. P. E., and Clement, B. M., 1986. Synchroneity of Pliocene planktonic foraminiferal datums in the North Atlantic. Mar. Micropaleontol., 10:295-307.
Weaver, P. P. E., and Clement, B. M., 1987. Magnetobiostratigraphy of planktonic foraminiferal datums: Deep Sea Drilling Project Leg 94, North Atlantic. In Ruddiman, W. F., Kidd, R. B., Thomas, E., et al., Init. Repts. DSDP, 94: Washington (U.S. Govt. Printing Office), 815-829.

Date of initial receipt: 14 September 1987

Date of acceptance: 20 June 1988

Ms 104B-157

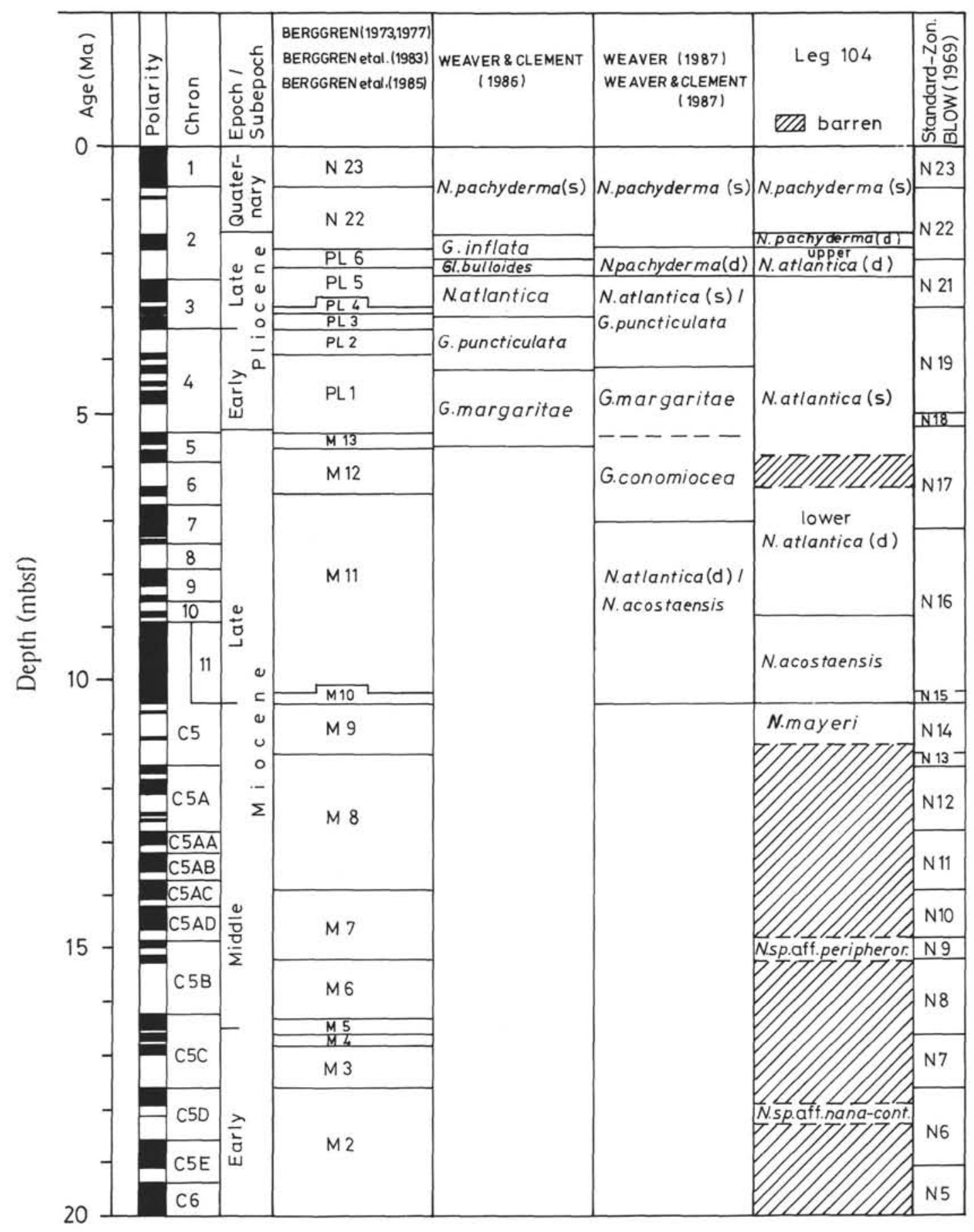

Figure 9. Correlation of Leg 104 planktonic foraminifer zones with North Atlantic zonal schemes and standard zonations. 


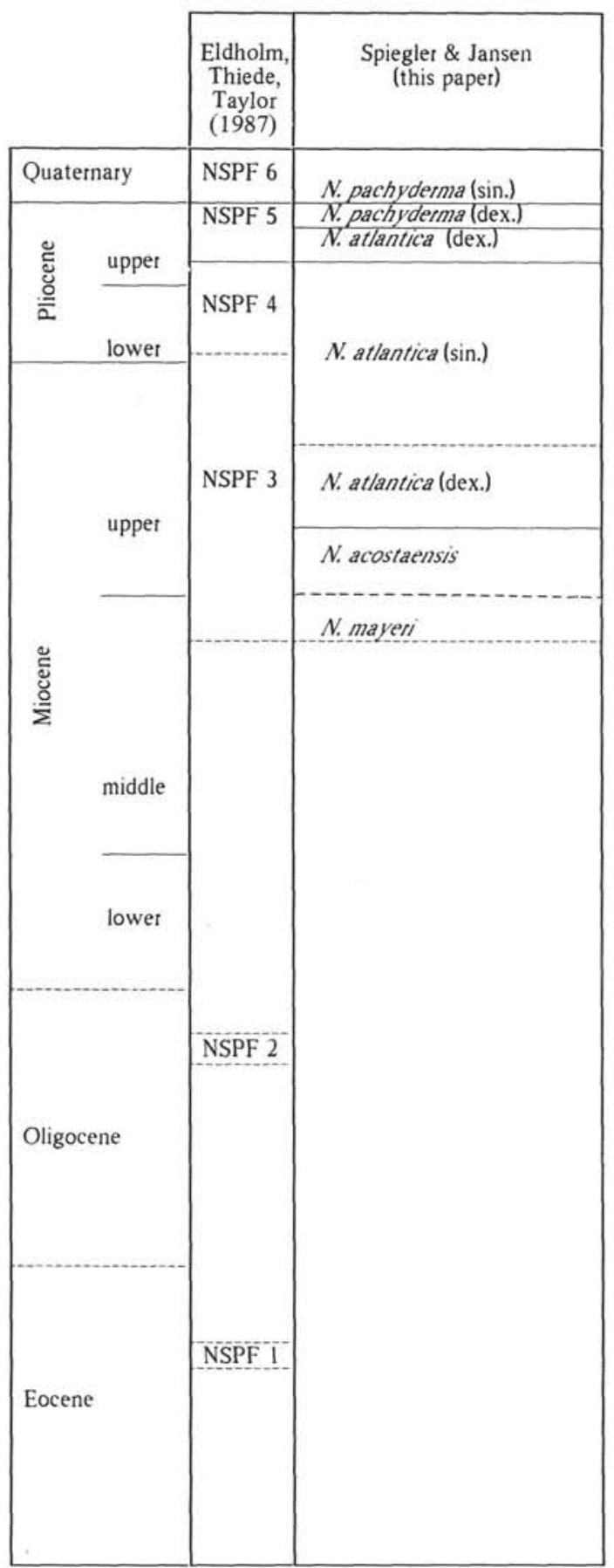

Figure 10. Planktonic foraminifer biostratigraphy of Leg 104. Comparison between the informal and preliminary zonation of Eldholm, Thiede, Taylor, et a1 . (1987) and the zonation outlined in this paper. NSPF = Norwegian Sea planktonic foraminifera.

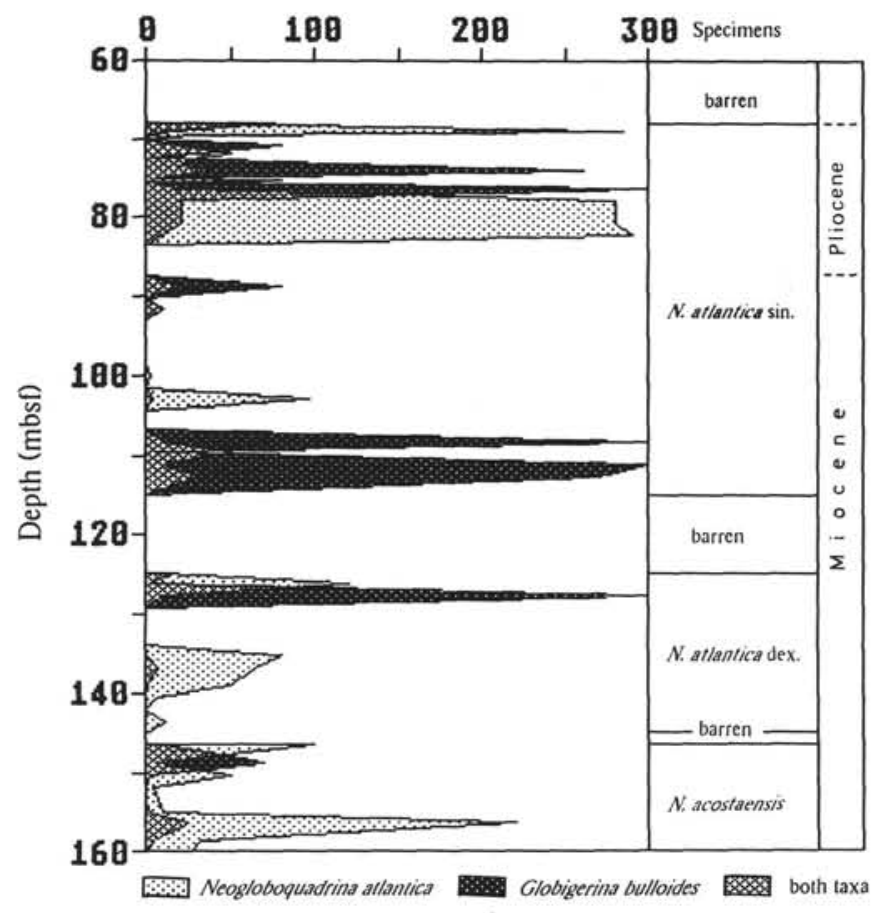

Figure 11. Abundances in fraction $>125 \mu \mathrm{m}$ of $N$. atlantica and $G l$. bulloides in the upper Miocene and Pliocene, Hole 642B. 


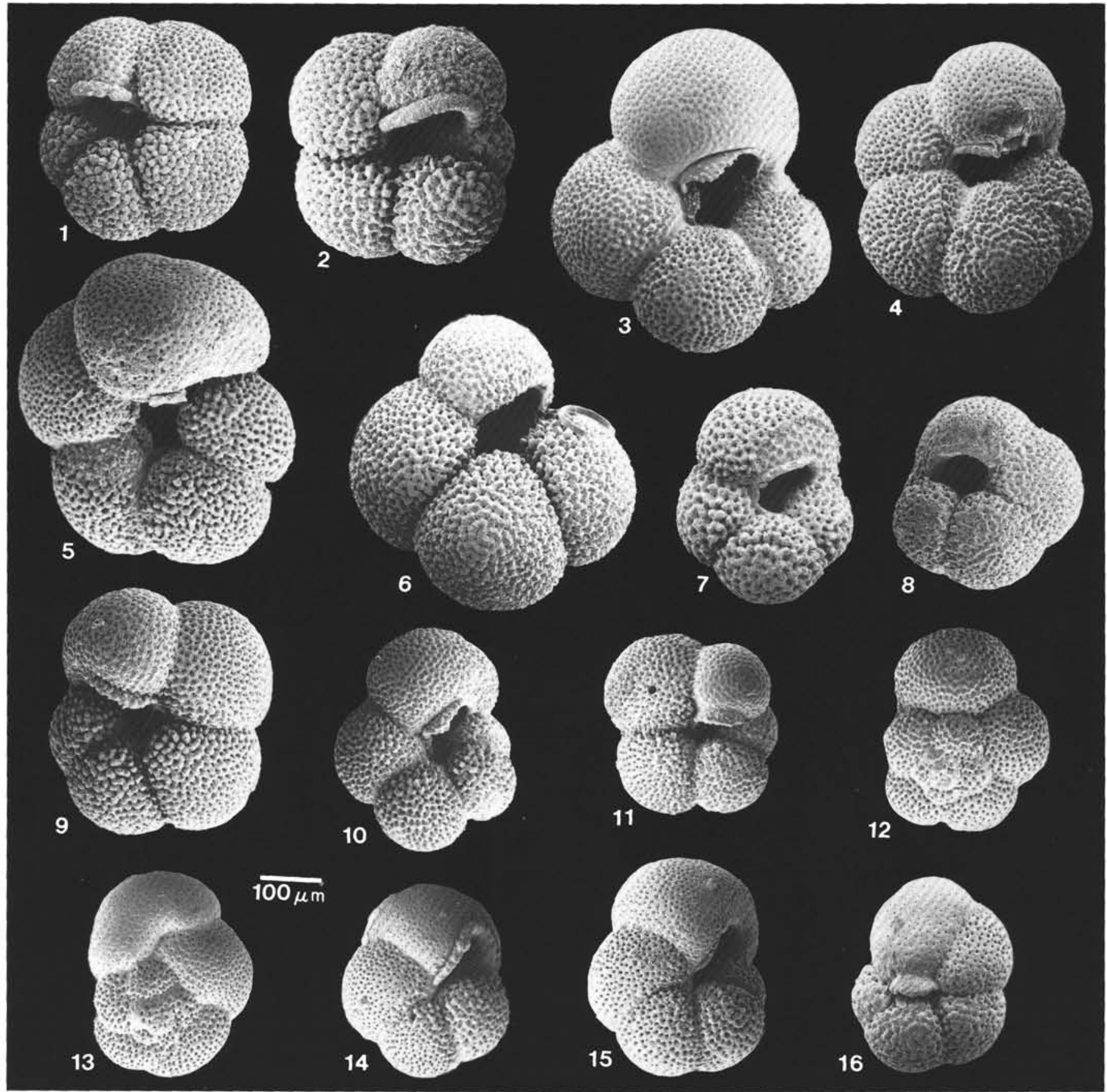

Plate 1. Planktonic foraminifers, Leg 104. 1-3. Neogloboquadrina dutertri (Orbigny, 1839). 1. Dextral coiling form, Section 104-642B-15-2, 113 cm. 2. Sinistral coiling form, Section 104-642B-12-6, $61 \mathrm{~cm}$. 3. Same for Section 104-642B-17-6, $116 \mathrm{~cm}$. 4-5. Neogloboquadrina praehumerosa (Natori, 1976). 4. Section 104-642B-18-1, $114 \mathrm{~cm}$. 5. Section 104-642B-18-6, $114 \mathrm{~cm}$. 6. Neogloboquadrina atlantica (Berggren, 1972) sinistral coiling form, Section 104-642C-9-1, $116 \mathrm{~cm}$. 7. Neogloboquadrina continuosa (Blow, 1959), Section 104-642B-11-5, $54 \mathrm{~cm}$. 8. Neogloboquadrina sp. transitional form between nana and continuosa, Section 104-643A-16-3, $38 \mathrm{~cm}$. 9-12. Neogloboquadrina acostaensis (Blow 1959). Section 104642C-19-6, $82 \mathrm{~cm}$. 13-15. Neogloboquadrina mayeri (Cushman and Ellisor, 1939). 13-14. Section 104-642C-20-1, 82 cm. 15. Section 104-642B$19-4,115 \mathrm{~cm}$. 16. Neogloboquadrina sp., aff. peripheroronda (Blow and Banner, 1966), Section 104-642B-19-4, $115 \mathrm{~cm}$. Scale: $1 \mathrm{~cm}=100 \mu \mathrm{m}$. The material is stored at the Geologisch-Paläontologisches Institut und Museum, Kiel, FRG, registration numbers 3562-3577. 

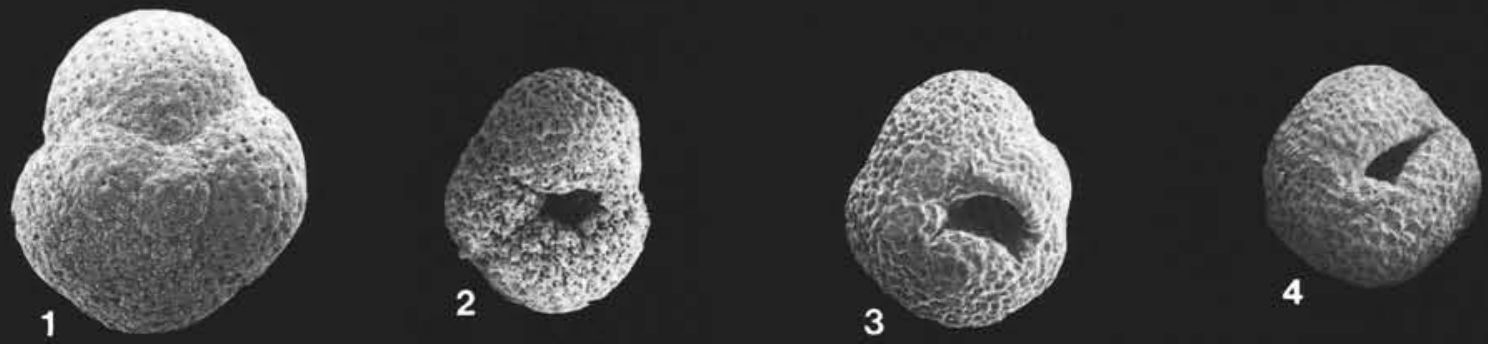

$100 \mu \mathrm{m}$
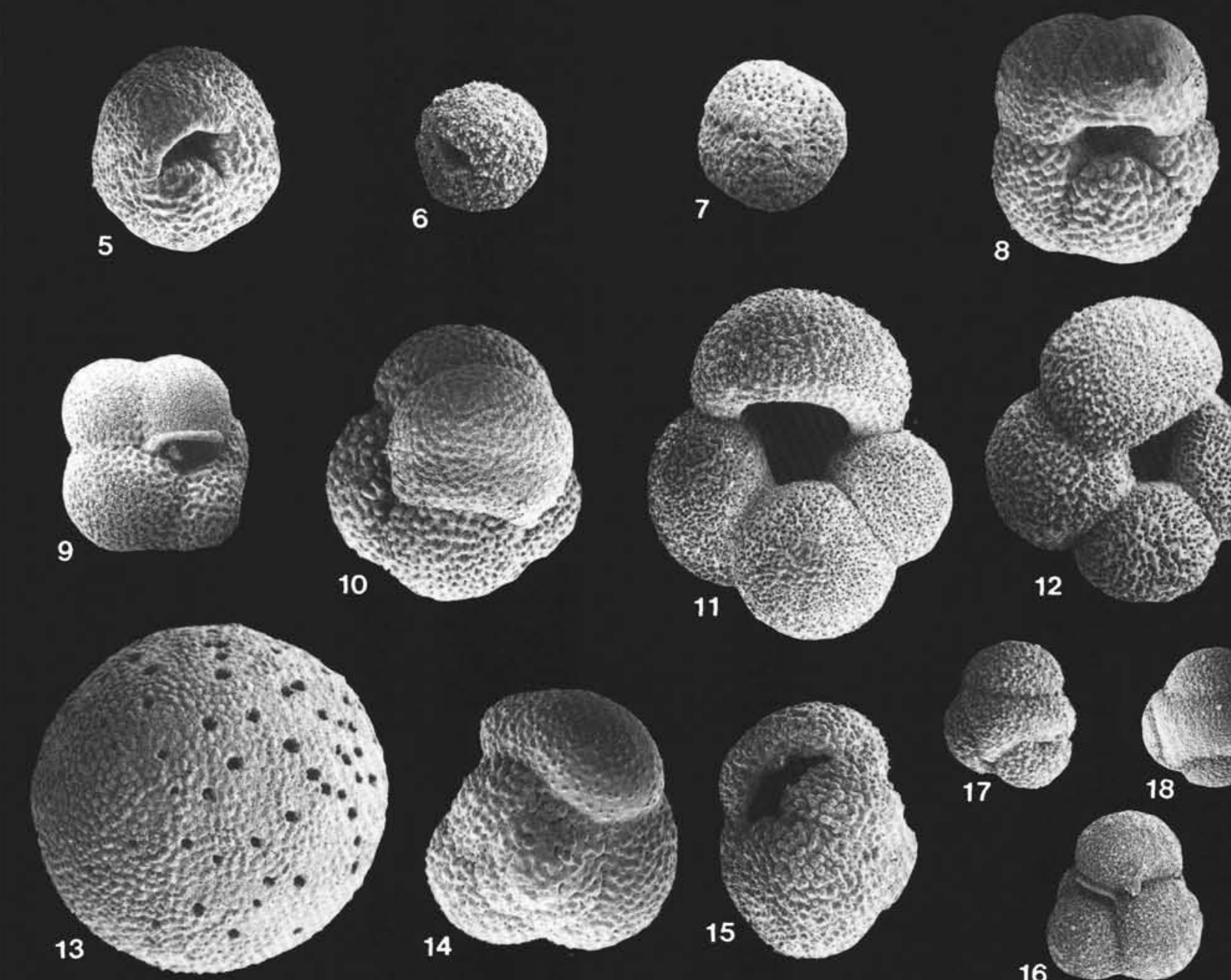

8
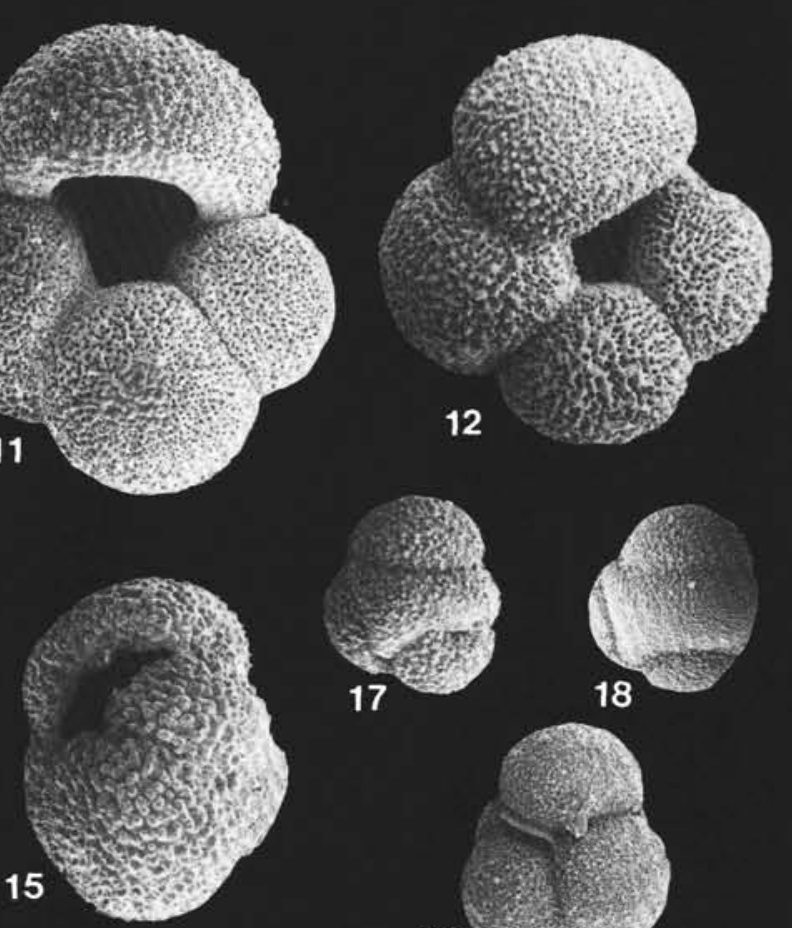

17
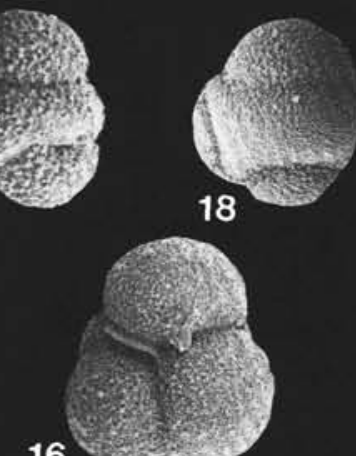

18

16

Plate 2. Planktonic foraminifers, Leg 104. 1-7. Neogloboquadrina pachyderma (Ehrenberg, 1861). 1. Sinistral enrolled form, spiral view, Section 104-642B-1-1, $96 \mathrm{~cm}$. 2. Sinistral enrolled form, umbilical view, Section 104-642B-1-2, $96 \mathrm{~cm}$. 3. Section 104-642B-5-3, $78 \mathrm{~cm}$. 4. Sinistral enrolled, heavy encrusted form, Section $643 \mathrm{~A}-3-3,40 \mathrm{~cm}$. 5-6. Dextral enrolled, heavy encrusted forms. 5. Section 104-644A-4-4, 42 cm. 6. 104642B-2-6, $53 \mathrm{~cm}$. 7. Sinistral enrolled, heavy encrusted form, section 104-642B-4-6, $43 \mathrm{~cm}$. 8-9. Neogloboquadrina cf. dutertrei (Orbigny, 1839), sinistral enrolled form, umbilical view. 8. Section 104-642B-4-5, $113 \mathrm{~cm}$. 9. Section 104-642B-8-2, $137 \mathrm{~cm}$. 10. Catapsydrax sp., Section 104642B-11-5, $54 \mathrm{~cm}$ with wall texture of Neogloboquadrina. 11. Globigerina bulloides (Orbigny, 1826), Section 104-642B-13-3, 104 cm. 12. Globigerinella obesa (Bolli, 1957), Section 104-642B-13-2, $104 \mathrm{~cm}$ (only single specimen). 13. Orbulina universa (Orbigny, 1839), Section 104-642B-10-2, $58 \mathrm{~cm}$. 14-15. Globoconella inflata (Orbigny, 1839). 14. Section 104-644A-15-1, $42 \mathrm{~cm}$. 15. 104-644A-30-1, $102 \mathrm{~cm}$. 16. Globigerinita glutinata (Egger, 1895), Section 104-642B-5-3, $78 \mathrm{~cm}$. 17-18. Globigerinita sp., Section 104-642B-11-3, $54 \mathrm{~cm}$. Scale: $1 \mathrm{~cm}=100 \mu \mathrm{m}$. The material is stored at the Geologisch-Paläontologisches Institut und Museum in Kiel, FRG, under registration numbers 3578-3595. 